\title{
Review of Geodiversity and Geoheritage related sessions at the European Geosciences Union General Assemblies
}

\author{
Maria BOSTENARU DAN \\ "Ion Mincu" University of Architecture and Urbanism, Faculty of Urbanism \\ Maria.Bostenaru-Dan@alumni.uni-karlsruhe.de
}

\begin{abstract}
Sessions related to geoheritage have been held under different convenorships and titles since 2012 at the European Geosciences Union General Assembly in Vienna. 2020 was a special year, since the session was held online. The author participated with a contribution in 2019 and without one in 2020, and it was an occasion to compare a physical session with oral and poster presentations and a splinter meeting to a digital session.
\end{abstract}

Keywords: geopark, Chaîne des Puys, Piedmont, rural landscape, geoproduct, agricultural landscape, natural heritage

\section{OVERVIEW}

Since 2012, a series of sessions on geodiversity and geoheritage has been held at the European Geosciences Union in Vienna, co-organised by different divisions, including education and outreach sessions. The titles and topics have changed over the years, while still touching on geodiversity and geoheritage, and so have the contributed papers. At the beginning, the same three conveners organised the session, but then the number grew, and the main convener rotated. A review of the first edition was provided by Vasiljevic (2012). Some of the papers were published (e.g. Coratza and Panizza, 2017).

\section{EVOLUTION AFTER YEARS}

The rows below list the years when the sessions were held, the organising divisions, exact titles, conveners, and topics covered.

-2012: SSS12.3/EOS11 Geodiversity and geoheritage in university education and research (co-organized). Convener: E. Cammeraat | CoConveners: E. Reynard, H. van den Ancker.
The topics tackled in 2012 were: overview of university teaching and research programmes; regional geoheritage studies - from inventory and classification to practical use (tourism and culture); geodiversity; new tools for teaching; methods, discussions; geodiversity, nature management and spatial planning.

-2013: SSS6.3/GM1.5 Geodiversity and geoheritage in geoscience research (co-organized). Convener: Emmanuel Reynard | Co-Conveners: Hanneke van den Ancker, Erik Cammeraat.

In 2013, the topics for oral presentations were scientific issues and methodological issues. Poster topics covered a wider range: geodiversity, geoheritage inventories, geoheritage management, and dissemination of knowledge on geoheritage.

-2014: SSS1.2/GM1.12 Geoheritage: Integrating geo- and biodiversity research (co-organized). Convener: Emmanuel Reynard | Co-Conveners: Grazina Skridlaite, Hanneke van den Ancker.

In 2014, the topics linked geodiversity and biodiversity, and geodiversity and geoheritage.

- 2015: SSS9.11/EOS10/GM4.4 Geoheritage, Geodiversity and Landscapes: a key issue for present and future studies (co-organized). 
Conveners: Paola Coratza, Zbigniew Zwoliński, Benjamin van Wyk de Vries | Co-Conveners: Marco Giardino, Alicja Najwer, Hanneke van den Ancker, Sjoerd Kluiving, Emmanuel Reynard, Erika Vye, Thomas Kisser, Stefanie Zecha (including a splinter meeting, and a town hall meeting on TM6. World Heritage Perspectives and the Chaîne des Puys and Limagne Fault Project, Convener: Benjamin van Wyk de Vries.

In 2015, the topics were geodiversity, geoheritage and cultural landscape; geodiversity, geoheritage and geomorphology; geodiversity, geoheritage and geoconservation-enhancement; geodiversity, geoheritage and education.

-2016: SSS3.6/EOS7 Geoheritage and Geodiversity Matter: Themes, Links and Interactions (co-organized). Conveners: Paola Coratza, Benjamin van Wyk de Vries, Zbigniew Zwoliński | Co-Conveners: Marco Giardino, Hanneke van den Ancker, Emmanuel Reynard, Sjoerd Kluiving, Thomas Kisser, Alicja Najwer, Erika Vye, Stefanie Zecha

In 2016, the topics were geodiversity and geoheritage: definitions and methods; the relationship between geodiversity, biodiversity and cultural heritage; education, conservation and geotourism.

-2017: GM1.3/EOS19/SSS3.12 Geodiversity and Geoheritage (co-organized). Conveners: Paola Coratza, Zbigniew Zwoliński, Benjamin van Wyk de Vries | Co-Conveners: Marco Giardino, Emmanuel Reynard, Hanneke van den Ancker, Sjoerd Kluiving, Alicja Najwer, Erika Vye, Stefanie Zecha, Kevin Page (including a splinter meeting)

In 2017, the topics were simply geoheritage and geodiversity.

-2018: GM1.6/EOS19 Geodiversity and geoheritage: pending and emerging issues and challenges (co-sponsored by JpGU) (co-organized). Convener: Fabien Hobléa | Co-Conveners: José Brilha, Paola Coratza, Marco Giardino, Kevin Page, Dolores Pereira, Zbigniew Zwoliński, Alicja Najwer (including a splinter meeting).

In 2018, the topics were geodiversity and geoheritage concepts and methods: looking for standards?; geoheritage and heritage stones as cultural resources for facing global change and natural risk (Protecting Geodiversity, Geoheritage and Heritage Stones); innovative concepts, initiatives and experiences in geoheritage and geodiversity management and promotion; geodiversity and geoheritage within UNESCO World Heritage sites and Geoparks.

-2019: ITS3.9/GM6.1/ERE7.4/GMPV7.15/ SSS13.29 Geodiversity and Geoheritage (cosponsored by JpGU). Convener: Marco Giardino | Co-conveners: Paola Coratza, Alicja Najwer, Karoly Nemeth, Benjamin van Wyk de Vries (including a splinter meeting).

In 2019, the topics were society, climate change and geodiversity; geo- to ecosystem services and geoheritage; towards a fruitful integration/ collaboration of international designations, geodiversity, geosites and geoheritage analysis at multiple spatial scales, virtual and augmented reality, and geoheritage.

-2020: GM12.1 Co-organized by EOS6, co-sponsored by APG and IAG Essential variables influencing geodiversity: contributions to geoheritage in response to global change. Convener: Zbigniew Zwoliński | Co-conveners: Irene Bollati, Paola Coratza, Marco Giardino, Franziska Schrodt

As the 2020 session was held online, there were no more subdivisions of topics.

The abbreviations stand for:

European Geosciences Union divisions: SSS $=$ Soil System Sciences

EOS $=$ Education and Outreach Sessions

$\mathrm{GM}=$ Geomorphology

ITS = Inter- and Trans-disciplinary Sessions

ERE $=$ Energy, Resources and the Environment

GMPV $=$ Geochemistry, Mineralogy, Petrology \&

Volcanology

Co-organisers:

IAG $=$ International Association of

Geomorphologists

APG $=$ Association of Polish Geomorphologists

\section{DISCUSSION AND CONCLUSIONS}

Figure 1 shows how the number of contributions varied over years, from one to four oral blocks and posters, respectively. The papers focused either on methods, as already mentioned, or on case studies. Most case studies were presented as posters, and covered both geodiversity and geoheritage. Figure 2 
shows an overview of the geographical distribution of case studies, using a different colour for each year. As it can be seen, while the reach is global, the focus was on Europe, for which a detailed view is provided. Figure 3 shows the ratio between case studies and methodologies.

At times, case studies tackle common approaches in a given country, while in others specific sites are presented (e.g. a city for geodiversity, or a national park for geoheritage). Some case studies are brought back as new data becomes available, e.g. Piedmont (Giordano et al, 2016, Rolfo et al, 2015, to name just a few publications), or the Dutch landscape paintings, Tenerife, Emilia Appenines that focused on mud volcanoes. A case that re-emerged over several years was the UNESCO proposal for Chaîne des Puys. In this context, IUCN's designations were dealt with repeatedly, while a number of other papers dealt with geoparks.

The previously mentioned location, the Piedmont region, was covered by a (co)convener of the conference a number of times, and was visited by the author of the review in 2018, in the context of the MoMoWo conference, when the author participated in the session on "Women and tourism", which covered first women tourists in the Alps. Excursions explored the heritage of Turin (Fig. 4), which in the EGU context was covered by Borghi et al, 2014, in a paper on the stone material used in the city seen as geoheritage. This was not entirely new to the author, who in 2006 organised a session on the topic GMPV10 "Challenges to historical materials in urban/anthropic environment", which later on resulted in a book (Bostenaru et al, 2009) in synergy with the running series on "Natural stone resources for historical monuments" convened by Richard Prykril, Ákos Török and collaborators. The topic is also relevant for the other site of Chaîne des Puys (Vereb et al, 2020). Excursions in the surroundings were made to explore Ivrea, which at the time was being reviewed as a World Heritage Site, and discussions were later on held on Susa Valley and Grande Traversata delle Alpi.

The author of the review participated at the 2019 session with a presentation on Rome's geoheritage (a previously approached topic) and experienced a part of the traditional oral and poster blocks, and also attended the splinter meeting, an event featured most years. The splinter meeting was dedicated to geoproducts. This is a typical approach for landscape conferences. For example, the Le Notre conferences also feature field trips and local food. In 2018, at the final COST RELY conference, coorganized with PECSRL (Permanent European Conference for the Study of the Rural Landscape), the author had the occasion to experience the Chaîne des Puys landscape to which, in one of the previous years, this session dedicated a town hall meeting (Bostenaru, 2020). The PECSRL conference allowed participants to discover the topics it featured, from the geodiversity of Clermont-Ferrand, which was also the subject of a presentation held at the EGU conference (published in Vereb et al, 2020), to geoproducts sourced in the natural park in numerous field trips, along with the landscape itself, which participants were able to choose to discover and enjoy by train, bus or trekking (Fig. 5).While the splinter meeting featured local geoproducts, the actual landscape - a landscape of pastoralism - was presented through photographs. Moreover, participants were handed flyers that presented strategies implemented by international associations on the topics that were being discussed.

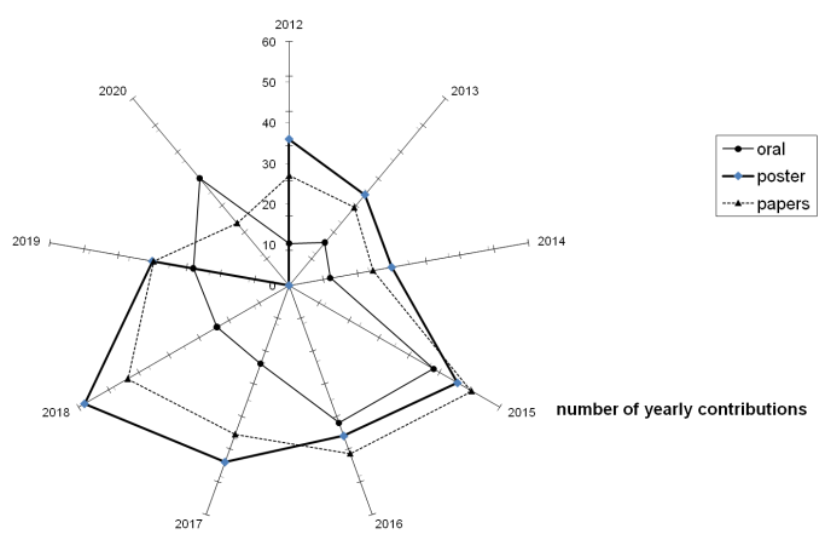

Figure 1 Number of yearly contributions

The digital Sharing Geoscience Online was organised by the EGU in several phases. Presentations could be uploaded so that participants could view and discuss them prior to and after the conference (one month before, and one month after the conference). During the conference, participants could communicate via an unrecorded group chat, which also introduced the so-called displays that 
allowed users to submit PPT and video files, and then the floor was open to questions. This way, significantly more questions could be asked. A special issue in a MDPI journal is currently being planned.

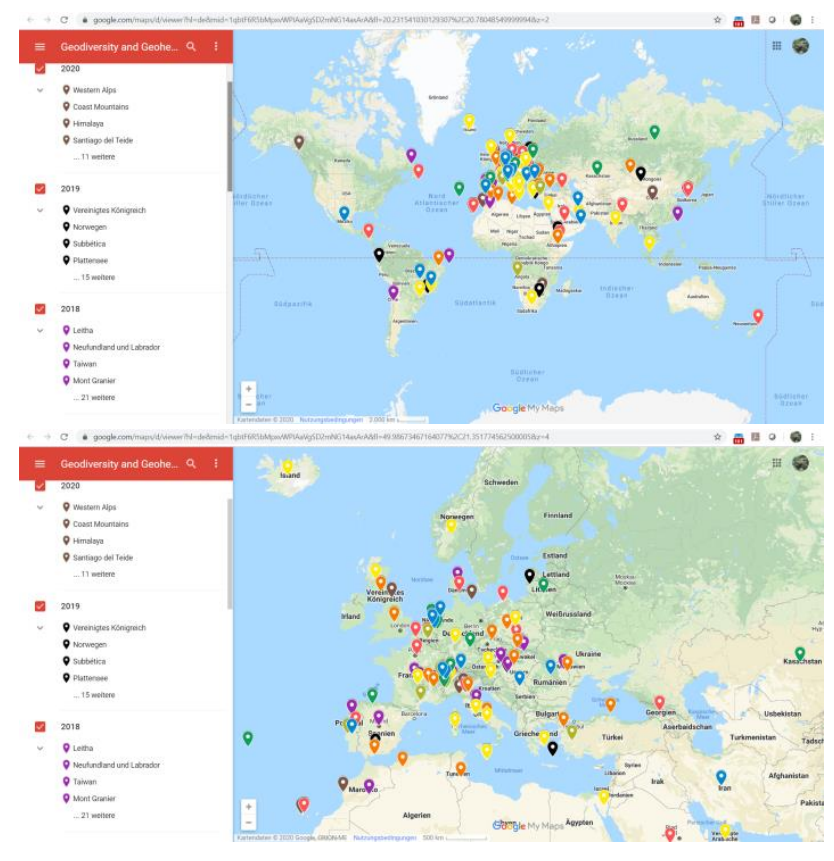

Figure 2 Map of case studies: worldwide and focus on Europe. Full map available here:

https://www.google.com/maps/d/drive?state $=\% 7 B \% 22 i d$ s\%22\%3A\%5B\%221qbtF6R5bMpxvWPIAaVgSD2mNG1 4asArA\%22\%5D\%2C\%22action\%22\%3A\%22open\%22 $\% 2 C \% 22$ userId\%22\%3A\%22103245202827861421792 $\% 22 \% 7 D \& u s p=$ sharing

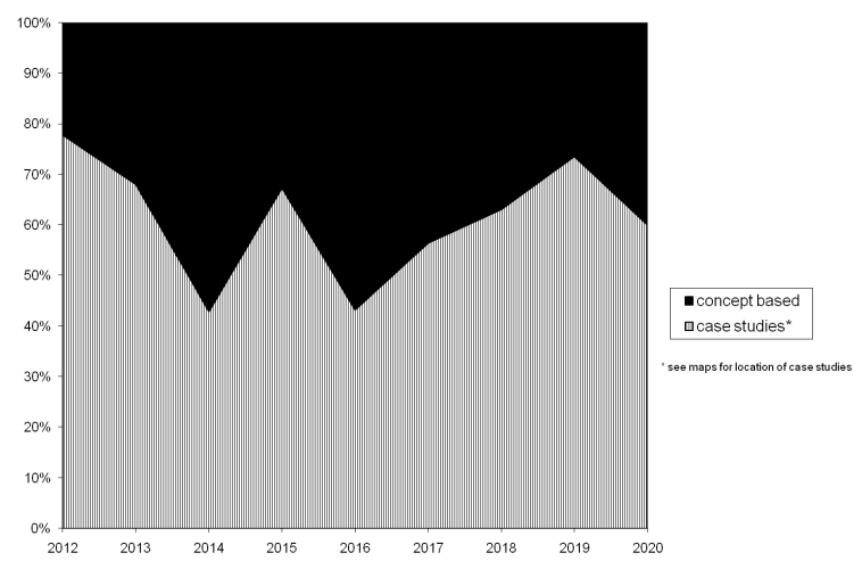

Figure 3 Number of concept based research abstracts/case studies
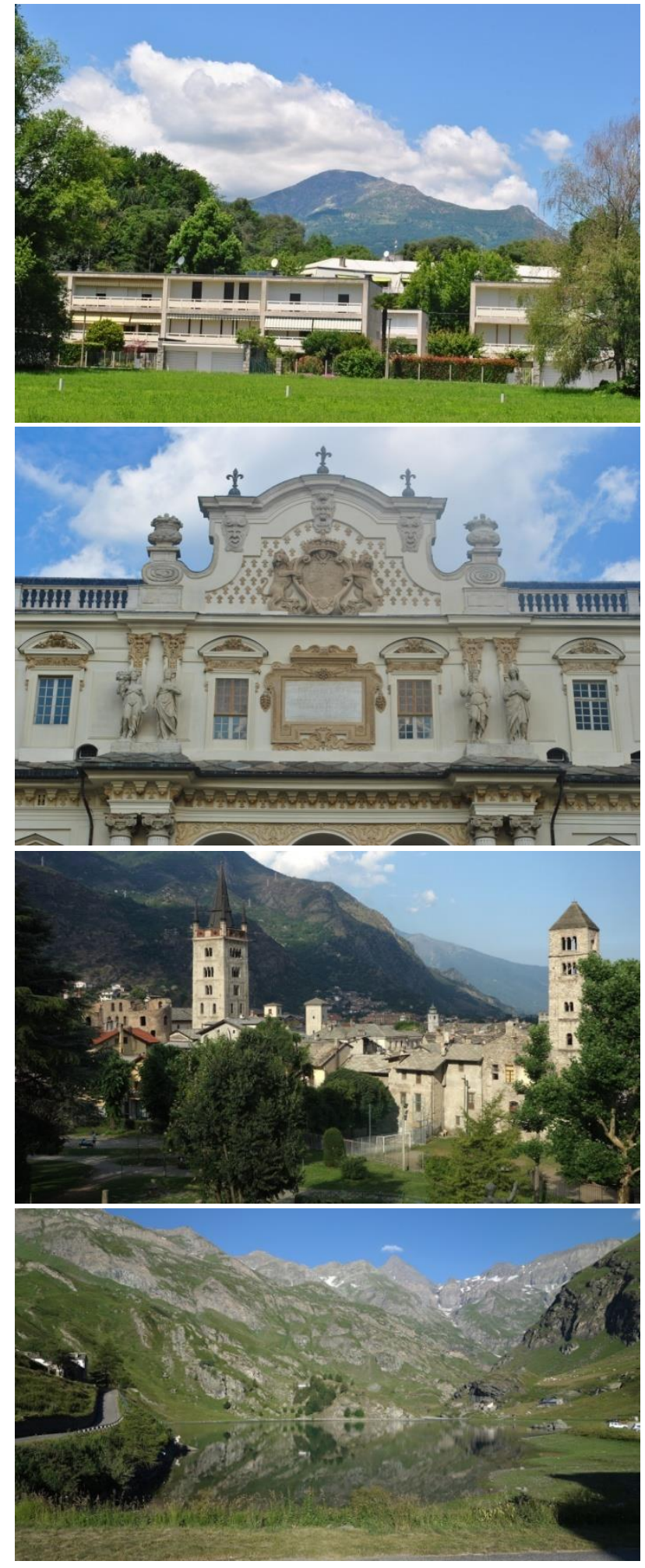

Figure 4 Piedmont region: World Heritage Site Ivrea and the Piedmont Alps landscape, Stone ornaments at the Architecture Faculty (Photos: M. Bostenaru), Susa, the valley covered by the study and local alpine landscape (Photos: J. Meinecke) 

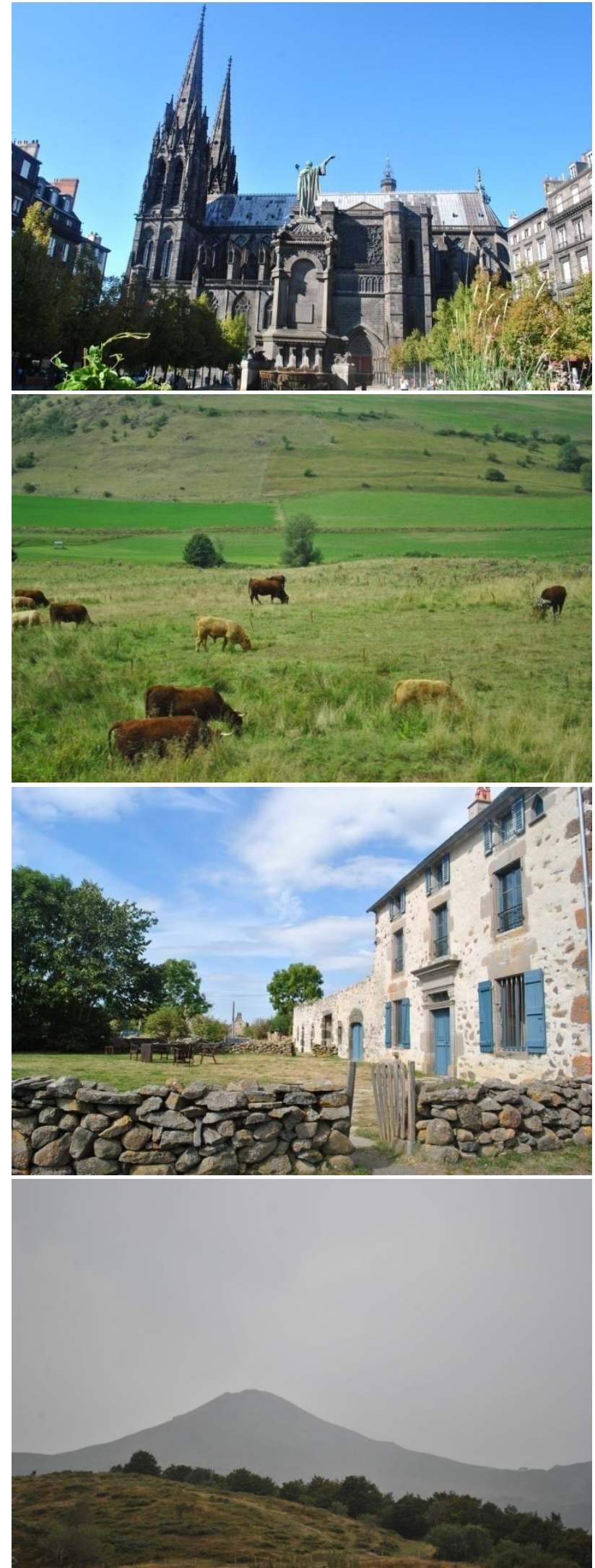

Figure 5 Chaîne des Puys landscape: volcanic geodiversity in Clermont-Ferrand, agriculture for geoproducts, "sur les chemins noirs" accommodation in a hamlet, Puy Mary volcano, similar to the UNESCO site. Photos: M. Bostenaru
Although it was not a visual session, such as Zoom-supported conferences or slide-based presentations, in order to account for the large number of attendees and their potential technical issues, the chat was a slow and tiring medium. Consequently, the conveners opted for a google doc to collect questions and answers (a unique option among sessions), which was also used to archive the session. A larger number of attendees could join, similarly to physical meetings.

\section{REFERENCES}

Borghi, A., d'Atri, A., Martire, L. et al. (2014) Fragments of the Western Alpine Chain as Historic Ornamental Stones in Turin (Italy): Enhancement of Urban Geological Heritage through Geotourism Geoheritage 6: 41-55, doi: 10.1007/s12371-013-0091-7

Bostenaru Dan, M., Přikryl, R., Török, Á. (2010), Materials, Technologies and Practice in Historic Heritage Structures, Springer, Dordrecht, doi: 10.1007/978-90-481-2684-2

Bostenaru Dan, M. (2020), PECSRL 2018: European Landscapes for Quality of Life, 3-9 September 2018, Clermont-Ferrand and Mende, France, Revista de sociologie românească, accepted

Coratza P., Panizza M. (2017), Goethe's Italian Journey and the Geological Landscape. In: Soldati M., Marchetti M. (eds) Landscapes and Landforms of Italy. World Geomorphological Landscapes. Springer, Cham, doi: 10.1007/978-3-319-26194-2_44

Giordano, E., Giardino, M., Perotti, L. et al. (2016) Following the Tracks of Charlemagne in the Cottian Alps. The Cultural and Geological Heritage of the Franks Trail (Susa Valley, Piemonte, NW Italy). Geoheritage 8: 293-300, doi:10.1007/s12371-015-0158-8

Rolfo, F., Benna, P., Cadoppi, P. et al. (2015)The Monviso Massif and the Cottian Alps as Symbols of the Alpine Chain and Geological Heritage in Piemonte, Italy. Geoheritage 7: 65-84, doi: 10.1007/s12371-014-0097-9

Vasiljević, D.A. (2012), Conference Report: Geodiversity and Geoheritage Session at EGU General Assembly 2012, 22-27 April 2012, Vienna, Austria. Geoheritage 4: 287-290, doi: 10.1007/s12371-0120067-z

Vereb V., van Wyk de Vries, B., Guilbaud, M.-N., Karátson, D. (2020), The Urban Geoheritage of Clermont-Ferrand: From Inventory to Management, QuaestionesGeographicae | Ahead of Publication. doi: 10.2478/quageo-2020-0020 